\title{
Ttsl, a Key Regulator of Rhizobium Species NGR234 Is Required for Type III-Dependent Protein Secretion and Synthesis of Rhamnose-Rich Polysaccharides
}

\author{
Corinne Marie, ${ }^{1}$ William J. Deakin, ${ }^{1}$ Tuula Ojanen-Reuhs, ${ }^{2}$ Ericka Diallo, ${ }^{1}$ Brad Reuhs, ${ }^{2}$ William J. \\ Broughton, ${ }^{1}$ and Xavier Perret ${ }^{1}$
}

${ }^{1}$ LBMPS, Département de Biologie Végétale, Sciences III, 30 quai Ernest-Ansermet, University of Geneva, CH-1211 Geneva 4, Switzerland; ${ }^{2}$ Whistler Center for Carbohydrate Research, Department of Food Science, Purdue University, 1160 Food Science Building, West Lafayette, IN 47907-1160, U.S.A.

Submitted 4 February 2004. Accepted 1 May 2004.

Formation of nitrogen-fixing nodules on legume roots by Rhizobium sp. NGR234 requires an array of bacterial factors, including nodulation outer proteins (Nops) secreted through a type III secretion system (TTSS). Secretion of Nops is abolished upon inactivation of $t$ ts $I$ (formerly y4xI), a protein with characteristics of two-component response regulators that was predicted to activate transcription of TTSS-related genes. During the symbiotic interaction, the phenotype of NGR $\Omega$ ttsI differs from that of a mutant with a nonfunctional secretion machine, however. This indicated that TtsI regulates the synthesis of other symbiotic factors as well. Conserved sequences, called $t$ ts boxes, proposed to act as binding sites for TtsI, were identified not only within the TTSS cluster but also in the promoter regions of i) genes predicted to encode homologs of virulence factors secreted by pathogenic bacteria, ii) loci involved in the synthesis of a rhamnose-rich component (rhamnan) of the lipopolysaccharides (LPS), and iii) open reading frames that play roles in plasmid partitioning. Transcription studies showed that TtsI and $t$ s boxes are required for the activation of TTSS-related genes and those involved in rhamnose synthesis. Furthermore, extraction of polysaccharides revealed that inactivation of $t$ ts I abolishes the synthesis of the rhamnan component of the LPS. The phenotypes of mutants impaired in TTSS-dependent protein secretion, rhamnan synthesis, or in both functions were compared to assess the roles of some of the TtsI-controlled factors during symbiosis.

Formation of nitrogen-fixing root nodules is the result of symbioses between plants of the legume family and bacteria commonly known as rhizobia. From the outset, the two partners exchange a series of molecular signals. Association of plant-produced flavonoids with the bacterial NodD proteins leads to transcriptional activation of nodulation genes, many of which are required for the synthesis of Nod-factors. Nodfactors are lipo-chito-oligosaccharides that are indispensable for root infection by rhizobial strains and initiation of nodule genesis. Inside nodules, bacteria reduce nitrogen to ammonia

Corresponding author: W. J. Broughton: Telephone: +1.41.223793108/9; Fax: +1.41.223793009; E-mail: william.broughton@ bioveg.unige.ch

C. Marie and W. J. Deakin contributed equally to this work.

Current address for C. Marie: Unité de Génétique Microbienne, INRA, Domaine de Vilvert, 78352 Jouy en Josas, France. for the benefit of the legume, in exchange for carbon sources from the plant.

In addition to Nod-factors, other bacterial products, such as polysaccharides and secreted proteins, play a role during symbiotic interactions (Broughton et al. 2000; Perret et al. 2000). As a gram-negative bacterium, Rhizobium spp. produce at least three types of cellular polysaccharides: i) exopolysaccharides, which are liberated into the medium; ii) capsular polysaccharides, which form an adherent cohesive layer on the cell surface; and iii) lipopolysaccharides (LPS), which are anchored in the outer leaflet of bacterial membranes via fatty acid moieties (Becker and Pühler 1998; Kannenberg et al. 1998).

In contrast to many rhizobia, Rhizobium sp. NGR234 has a broad host range. It nodulates more than 112 genera of the Leguminosae, as well as the nonlegume Parasponia andersonii (Pueppke and Broughton 1999). The promiscuity of this strain can be partly explained by the specific symbiotic factors it produces. When interacting with plants, NGR234 synthesizes a large family of Nod-factors (Broughton et al. 2000; Perret et al. 2000) as well as new types of LPS that contain a modified core oligosaccharide to which is linked an O-antigen called rhamnan (made of 10 to 12 repeating units of three $\alpha$ linked L-rhamnose residues) (Fraysse et al. 2002). Deletion of the genes encoding the enzymes involved in rhamnan synthesis leads to the formation of nodules with reduced nitrogen fixation ability on the roots of Vigna unguiculata and other legumes (Broughton et al. 2004). In addition, in the presence of flavonoids, NGR234 secretes, via a type III secretion system (TTSS), proteins called Nops (nodulation outer proteins). The secretion machine is thought to be composed of at least ten proteins termed Rhc (Rhizobium conserved) that span both bacterial membranes (Viprey et al. 1998). To date, six secreted proteins have been identified: NopA, NopB (formerly known as NolB), NopC, NopL, NopP, and NopX (Ausmees et al 2004; Marie et al. 2003; Viprey et al. 1998; W. J. Deakin, M. Saad, and X. Perret, unpublished data). Abolition of Nop secretion affects symbiotic processes on some plant species (Ausmees et al 2004; Marie et al. 2003; Viprey et al. 1998).

Although TTSS-dependent protein secretion requires flavonoids and NodD1, nod box-like sequences to which NodD1 binds were not identified in any of the promoter regions of the nop and $r$ c genes (Freiberg et al. 1997). Only one such cisregulatory element was found upstream of $t t s I$ (formerly called $\mathrm{y} 4 \mathrm{xI}$ ), inactivation of which abolished Nop secretion. TtsI shares characteristics of two-component response regulators (Marie et al. 2003; Viprey et al. 1998) and was proposed to act 
as an intermediary in the regulatory cascade between NodD1 and TTSS-related genes (Viprey et al. 1998). On all plants tested, however, the phenotype of the $t t s I$ mutant differs notably from that of a strain containing a nonfunctional secretion machine. This suggested that TtsI is also involved in the regulation of other genes as well as those related to type III secretion. Recently, Krause and associates (2002) identified, in the promoter regions of the nop and $r h c$ genes, conserved $c i s$ elements called $t t s$ boxes, to which TtsI might bind. Here, we have extended the search for $t$ ts boxes to the entire symbiotic plasmid of NGR234 (pNGR234a) and have found six additional regulatory elements outside the TTSS cluster. Three were located upstream of genes encoding putative proteins that may be secreted via the type III secretion machine. Another was found in the promoter region of genes that play a role in plasmid partitioning. Finally, two $t t s$ boxes were identified within the cluster of genes involved in rhamnan synthesis. Transcription studies showed that TtsI acts as an activator of genes involved in type III secretion and rhamnose synthesis in a tts-box-dependent manner. We also report that a ttsI mutant does not produce the rhamnan component of the LPS. To assess the symbiotic role of these factors that are under the control of TtsI, we compared the phenotype of the ttsI mutant with those of mutants affected in Nop secretion, rhamnose synthesis, or in both.

\section{RESULTS}

\section{Delineation of $t$ ts boxes upstream}

of TTSS-related open reading frames (ORF).

The requirement of flavonoids, NodD1, and TtsI for protein secretion suggested that TtsI could bind to cis-acting elements located upstream of TTSS genes. Comparison of promoter regions of the nop/rhc genes of various rhizobial strains led to the identification of short, conserved, nonpalindromic sequences called $t$ ts boxes (Krause et al. 2002) (Fig. 1A). Nucleotide analysis of the 536,165-bp pNGR234a revealed the presence of $11 \mathrm{tts}$ box-like elements (Fig. 1). Five were found in the TTSS cluster immediately upstream of nopL, nopX, nopB, nopP, and $n o p C$ (Fig. 2A). Thus, it appears that in this region the tts boxes are exclusively located upstream of genes encoding proteins secreted via the TTSS. Another three were found upstream of y4fR, y4lO, and y4zC (Fig. 2B), ORF that encode putative proteins that are homologous to virulence factors secreted in a TTSS-dependent manner by plant and animal pathogens (Freiberg et al. 1997; Marie et al. 2001). y4fR is homologous to YopM of Yersinia spp., whereas y4lO and y4zC are members of the YopJ/AvrBsT and YopT families of pathogenic factors, respectively (Freiberg et al. 1997; Marie et al. 2001). This suggests that these rhizobial proteins may also be secreted by NGR234 in a TtsI-dependent manner upon induction with flavonoids.

\section{$t t s$ boxes that regulate functions unrelated to TTSS.}

Three $t t s$ boxes were identified upstream of genes encoding proteins not thought to be related to type III secretion. One was found in the promoter region of $\mathrm{y} 4 \mathrm{mF}$ (Fig. $2 \mathrm{C}$ ). The stop codon of $\mathrm{y} 4 \mathrm{mF}$ overlaps the start codon of $\mathrm{y} 4 \mathrm{mE}$, suggesting that both genes form an operon. $\mathrm{y} 4 \mathrm{mFE}$ encodes proteins homologous to the NGR234 y4dLM and Escherichia coli HipAB proteins (Freiberg et al. 1997). HipA and HipB exhibit characteristics of the two-protein plasmid stabilization system that allows a lowcopy-number plasmid to be maintained in cell progeny (Falla and Chopra 1999). Cloning of either y4mFE or y4dLM of Rhizobium sp. NGR234 into a plasmid that is unstable in $R$. etli CNPAF512 confers $100 \%$ stability to the replicons, even after numerous cell divisions (Dombrecht et al. 2001), suggesting that these loci are involved in the stabilization of pNGR234a.
A

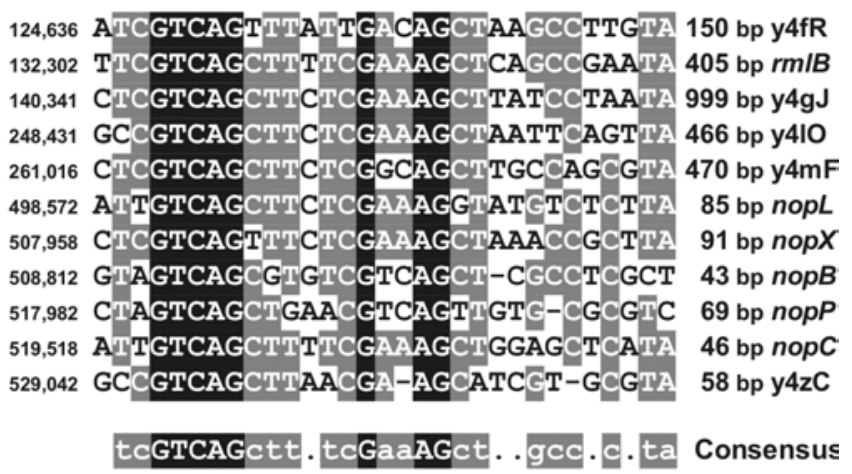

B

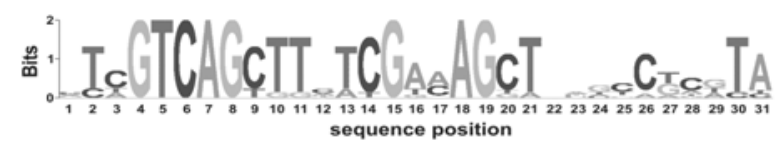

C

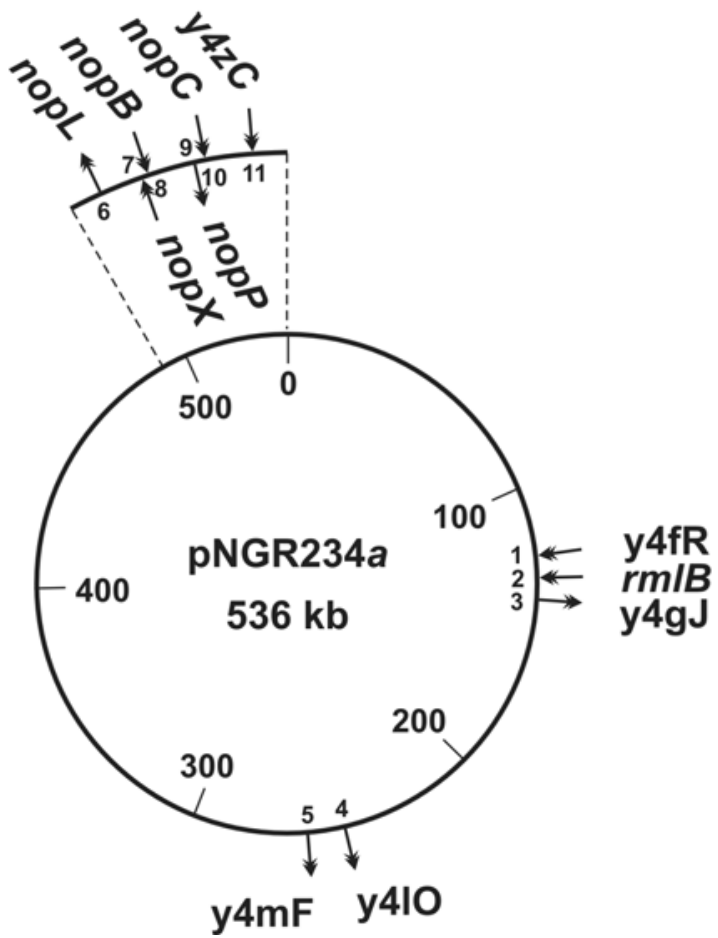

Fig. 1. $t$ ts boxes identified on the symbiotic plasmid of NGR234. A, Positions of $t$ ts boxes on pNGR234 $a$ are indicated on the left-hand side and correspond to the first " $\mathrm{T}$ " or "C" of the consensus sequence. The distance separating the last nucleotide of the $t$ ts box from the ATG of the coding sequence is indicated on the right-hand side. Nucleotides conserved among all of the $t$ ts boxes are shaded in black, whereas those highlighted in gray are present in the majority of the sequences. B, Consensus derived from the alignment of $t t s$ boxes. A perfect match would have a score of two bits. C, Location of $t$ ts boxes on pNGR234a. $t$ ts boxes located on the plus strand of the symbiotic plasmid are indicated with arrows oriented toward the center of the circle. Those from the minus strand are shown with arrows in the reverse orientation. The tts boxes are numbered as they are found on pNGR234a; the $t t s$ box of $\mathrm{y} 4 \mathrm{fR}$ is thus $\mathrm{TB} 1$, and that of $\mathrm{y} 4 \mathrm{zC}$ is $\mathrm{TB} 11$. 
Finally, two $t t s$ boxes were identified upstream of $r m l B$ and $\mathrm{y} 4 \mathrm{gJ}$. $\mathrm{y} 4 \mathrm{gJ}$ does not share any significant similarity with known proteins, whereas $r m l B, r m l D$, and $r m l A$ encode proteins that are homologous to enzymes involved in the synthesis of dTDP-L-rhamnose from glucose 1-phosphate. Deletion of $r m l B$ and the downstream genes ( $r m l D, r m l A$, and $w b g A)$ abolishes the synthesis of rhamnan (Broughton et al. 2004). WbgA is homologous to the Myxococcus xanthus WbgA protein that is required for $\mathrm{O}$-antigen biosynthesis, but its exact function remains unknown.

\section{TtsI is necessary for de novo production} of rhamnan as well as Nop synthesis.

The presence of a $t t s$ box upstream of $r m l B$ suggested that TtsI might also control the synthesis of rhamnose. To test the requirement of TtsI for the production of rhamnose-rich Oantigens, polysaccharides produced by the wild-type strain and various mutants were extracted with hot phenol (Fig. 3A). The rhamnan-containing LPS fractionate into the water phase and, when separated on polyacrylamide gels, appear as a group of bands reflecting different degrees of polymerization of rhamnan (Jabbouri et al. 1996). Figure 3A shows that not only did synthesis of the rhamnan require flavonoids, NodD1, and the $r m l B-w b g A$ genes but also required TtsI. Furthermore, introduction into NGR $\Omega$ ttsI of ttsI and its promoter, carried by the broad-host-range vector pLAFR-6 (plasmid pttsI), restored production of rhamnan.

Downstream of $t t s I$, two genes, $r h c C 2$ and $\mathrm{y} 4 \mathrm{xK}$, are transcribed in the same orientation (Fig. 2A). rhcC2 encodes a protein that belongs to the group of secretins that are thought to be required for the formation of the type III secretion apparatus. The amino acid sequence of $\mathrm{y} 4 \mathrm{xK}$ indicates that the protein could be a lipoprotein. Whereas introduction of pttsI into NGR $\Omega$ ttsI restored rhamnan synthesis (Fig. 3A), transconjugants were still blocked for protein secretion (Fig. 3B). This suggested that $t t s I$, $r h c C 2$, and $\mathrm{y} 4 \mathrm{xK}$ belong to the same transcription unit and that either $\mathrm{RhcC} 2$ or the protein encoded by $\mathrm{y} 4 \mathrm{xK}$ is required for protein secretion. It also explains why the symbiotic phenotype of NGR $\Omega t t s I$ ( $\mathrm{ptts} I$ ) resembles that of the $r h c N$ mutant (discussed below). For unknown reasons, it was not possible to clone $t t s I$, $r h c C 2$, and $\mathrm{y} 4 \mathrm{xK}$ into pLAFR-6 to allow complete complementation of NGR $\Omega$ ttsI to be tested.

Transcriptional activation of $\mathrm{nopB}$ and $\mathrm{rmlB}$ requires TtsI.

To confirm that TtsI acts as a transcriptional activator of the genes involved in TTSS-dependent protein secretion and rhamnose synthesis, various promoter regions were cloned upstream of a promoterless lacZ gene carried by pMP220 (Spaink et al. 1987). To test the requirement for regulatory proteins, the constructs were mobilized into the NGR nodD1 and NGR $\Omega$ ttsI mutants. At first, we analyzed the promoter activity of the intergenic region located between $r h c C 1$ and $n o p B$, two genes that are divergently transcribed (Fig. 4A). rhc $C 1$ is mono-cistronic and is thought to encode an outer membrane component of the secretion machine, whereas nopB is the first gene of a large operon that extends to $r h c U$ (Perret et al. 2003) (Fig. 2A). Earlier work had shown that both $r h c C 1$ (then called $n o l W$ ) and $n o p B$ (nolB) were strongly induced by

\section{A TTSS cluster}

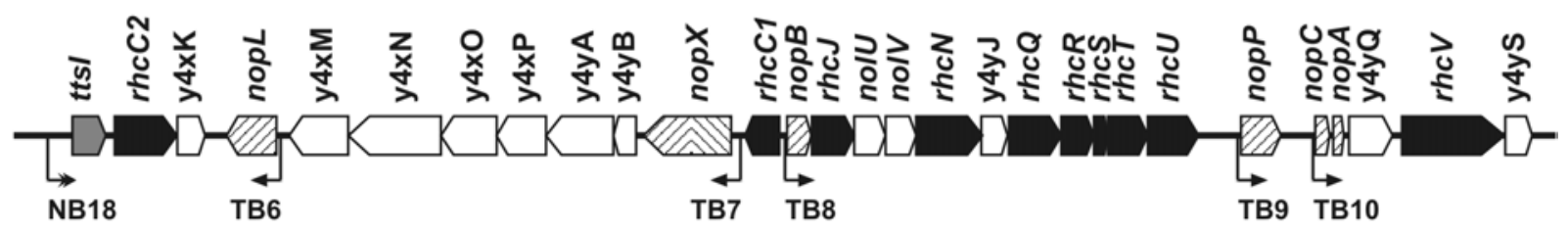

B genes encoding putative secreted proteins

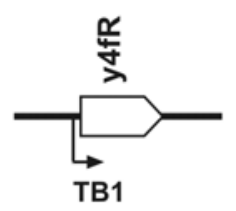

D genes involved in polysaccharide synthesis

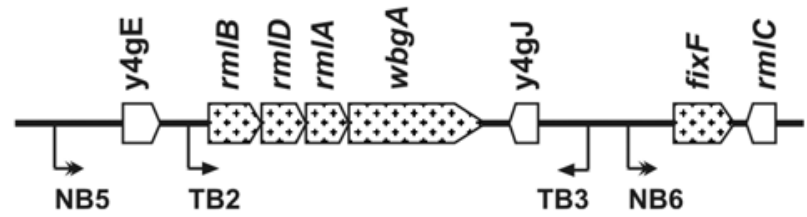

C genes involved in plasmid stabilization
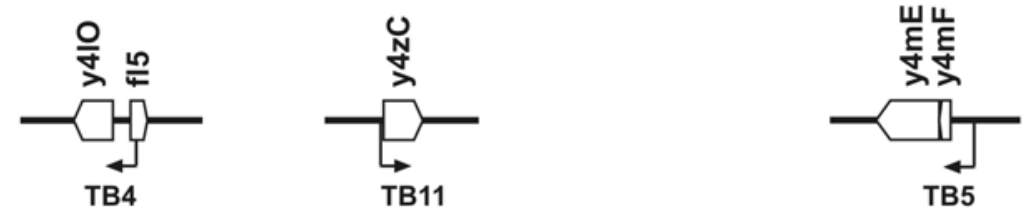

Fig. 2. Genetic organization and predicted functions of open reading frames (ORF) controlled by tts boxes. Eight $t$ ts boxes were identified in the promoter regions of genes that encode proteins A, known to be secreted (Nops) or B, thought to transit via the NGR234 type III secretion system. C, Another tts box was located upstream of y4mFE, shown to play a role in plasmid partitioning. D, Two other conserved tts boxes were found in the G section of pNGR234a. $r m l B, r m l D, r m l A$, and $r m l C$ (formerly $\mathrm{y} 4 \mathrm{gF}, \mathrm{y} 4 \mathrm{gG}, \mathrm{y} 4 \mathrm{gH}$, and $\mathrm{y} 4 \mathrm{gL}$, respectively) encode proteins with homology to enzymes involved in synthesis of dTDP-L-rhamnose from glucose 1-phosphate. fix $F$ and $w b g A$ encode putative glycosyltransferases. The function of $\mathrm{y} 4 \mathrm{gJ}$ is unknown. $\mathrm{y} 4 \mathrm{gE}$ and fl5 have homology with transposases. Genes are represented by arrows showing the sense of transcription. ttsI is shown in gray. Loci that encode components of the type III secretion machine are marked in black, and those coding for Nops are hatched. ORF required for rhamnan synthesis are shown as dotted arrows. nod $(\mathrm{NB})$ and $t$ s $(\mathrm{TB})$ boxes are represented by double arrowheads and black arrows (labeled TB1 to TB11), respectively. 
apigenin after $24 \mathrm{~h}$ (Hanin et al. 1998). The induction of nopB concurred with the presence of a tts box upstream of this gene, but the induction of $r h c C 1$ was unexpected, as no tts box is predicted upstream of this gene, suggesting that there could be alternative regulatory signals controlling TTSS-related genes. Thus, we reisolated from the transconjugants the reporter gene constructs used by Hanin and associates (1998), in order to confirm these results. The plasmids, however, did not have the published characteristics, and thus, we recloned the $r h c C 1$ and $n o p B$ promoter regions upstream of $l a c Z$, as previously described (Hanin et al. 1998). We then repeated the transcriptional analysis, using the same growth conditions that were used to test the 19 nod boxes of NGR234 (Kobayashi et al. 2004). The activity of the reporter gene was assayed at several timepoints to determine more accurately when induction began. In the presence of the inducer apigenin $\left(10^{-6} \mathrm{M}\right)$, high levels of $\beta$-galactosidase activity were measured in the wildtype strain when $l a c Z$ was fused to the nopB promoter (construct pMP220-B; Fig. 4A). When compared with the activity of the promoter that regulates the expression of the nodABCI JnolO operon (Fig. 4A, NGR234 pMP220-NBA), the transcription of $n o p B$ was clearly delayed (Fig. 4A, NGR234 pMP220-B) and started between 2 and $4 \mathrm{~h}$ after flavonoid induction. $\beta$-Galactosidase activities measured with the pMP220-B transconjugant strains NGR nodD1 and NGR $\Omega$ ttsI (Fig. 4A, $\Omega$ nodD1 pMP220-B and $\Omega$ ttsI pMP220$\mathrm{B}$, respectively) confirmed that both NodD1 and TtsI are required for $n o p B$ expression. These results are consistent with data obtained using DNA macroarrays (Perret et al. 1999) and with the NodD1- and flavonoid-dependent regulatory network proposed by Kobayashi and associates (2004). In contrast, $r h c C 1$ was expressed at lower levels and in a constitutive manner, corroborating the observation that the promoter region of nopB (but not $r h c C 1$ ) contains a tts box.

To study the regulation of genes involved in rhamnose synthesis, the $\mathrm{y} 4 \mathrm{gE}-\mathrm{rmlB}$ intergenic region was cloned into pMP220 (Fig. 4B, construct pMP220-rmlB). High levels of $\beta$ galactosidase activity were measured in the wild-type strain grown in the presence of apigenin [Fig. 4B, NGR234(pMP220-rmlB)], indicating that the cloned fragment contains a functional promoter. Transcriptional activation was flavonoid-, NodD1-, and TtsI-dependent (Fig. 4B, SnodD1 pMP220-rmlB and $\Omega$ ttsI pMP220-rmlB). To test whether the $t t s$ box is required for gene activation, a region of $119 \mathrm{bp}$ containing the putative cis-acting element was deleted from the $r m l B$ promoter region (Fig. 4B, plasmid pMP220- $\Delta r m l B$ ).
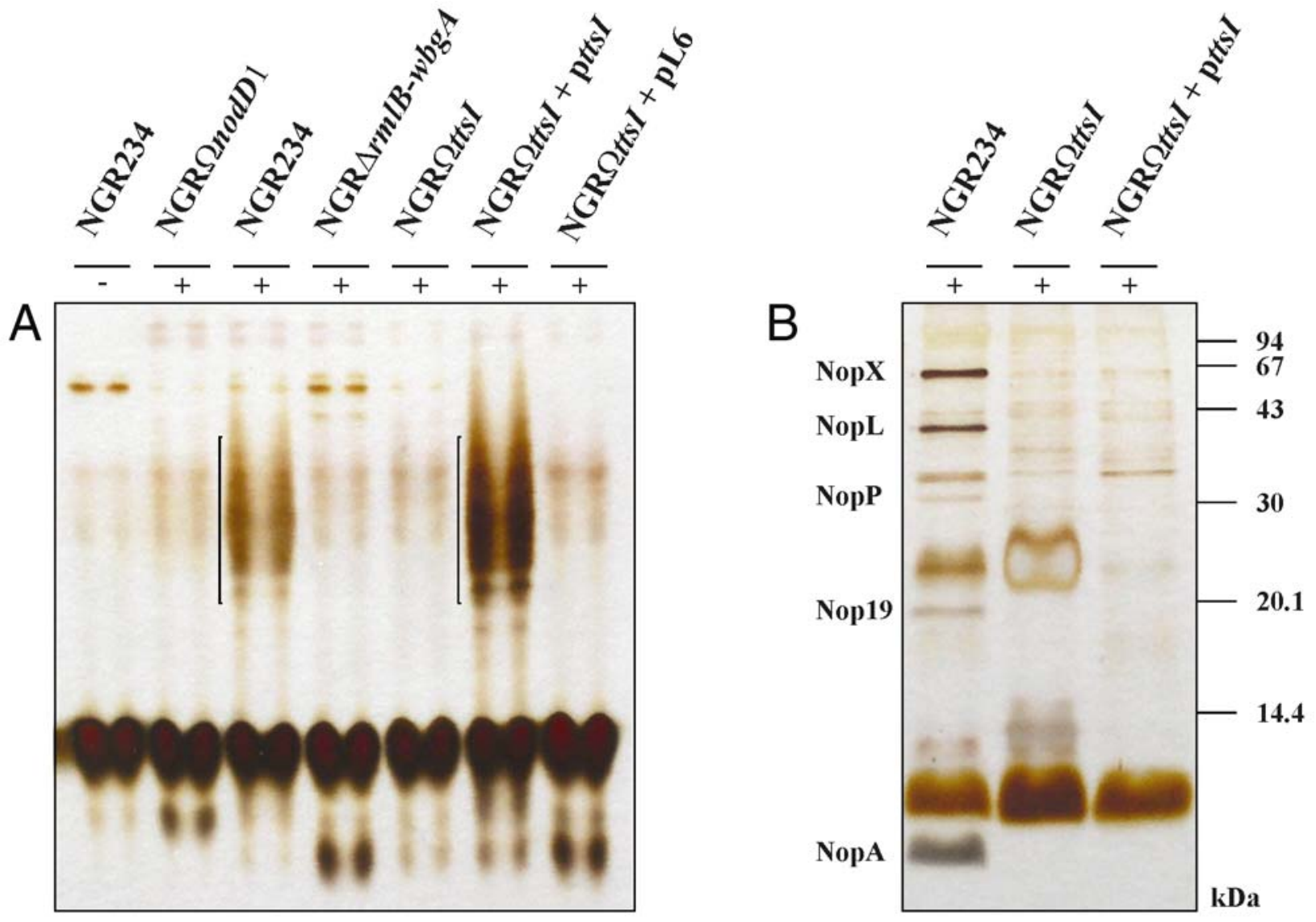

Fig. 3. A, TtsI is required for rhamnan synthesis. Polysaccharides synthesized by NGR234 and various mutants thereof grown in the presence (+) or absence $(-)$ of apigenin were extracted with hot phenol. Aqueous-phases were loaded onto polyacrylamide gels and were stained with silver nitrate. The synthesis of the rhamnan component (indicated with the black vertical line) of the lipopolysaccharides is flavonoid- and NodD1-dependent and requires the $r m l B$ - $w b g A$ genes as well as ttsI. Complementation of NGR $\Omega$ ttsI was obtained, after introduction into the mutant of pttsI that contains the regulatory gene cloned into pLAFR-6. In contrast, introduction of the vector alone (labeled as pL6) into NGR $\Omega$ ttsI did not change the polysaccharide profile of the mutant. B, Nop secretion by various NGR234 strains. Proteins secreted into the supernatants of various NGR234 strains were isolated and separated by sodium dodecyl sulfate-polyacrylamide gel electrophoresis. The nodulation outer proteins (Nops) secreted by NGR234 that have been identified are labeled. Introduction of pttsI into NGR $\Omega$ ttsI restored rhamnan synthesis but not Nop secretion. This suggested that mutation of ttsI impaired transcription or translation of downstream genes that probably encode proteins required for the formation of the secretion machine. Numbers on the right-hand side indicate the positions of the molecular weight standards. The extractions from NGR $\Omega$ ttsI show bands at about 25 and $14 \mathrm{kDa}$ whose production is increased. These bands are probably not proteinaceous, as they remain after proteinase $\mathrm{K}$ treatment of the samples (data not shown). The composition of the bands is unknown, but given the role of TtsI in polysaccharide metabolism, they might be a consequence of the inability of the ttsI mutant to synthesize rhamnan. 
When this construct was introduced into the wild-type strain, $\beta$-galactosidase activity was reduced to basal levels. Although at this stage, we cannot definitively rule out the possibility that other regulatory elements were also removed, it seems likely that the $t t s$ box is required for $r m l B$ transcription. Thus, TtsI activates the transcription of those genes whose promoter regions contain a tts box, suggesting that it is the binding site for the regulatory protein.

\section{Symbiotic implications}

of molecular signals under the control of TtsI.

Previously, we showed that abolition of Nop secretion has either no effect on nodulation or leads to a change (decrease or increase) in nodule number, depending upon the plant species tested (Ausmees et al 2004; Marie et al. 2003; Viprey et al. 1998). To determine the roles of Nops and rhamnose-rich LPS during the symbiotic interaction, mutants affected either in protein secretion (NGR $\Omega r h c N$ ) or in rhamnan synthesis (NGR $\Delta r m l B-w g b A$ ) were inoculated onto the two plant models that respond either positively or negatively to Nops, Tephrosia vogelii and Pachyrhizus tuberosus, respectively (Fig. 5). In parallel, to test whether the two TtsI-dependent symbiotic factors act in synergy or in an antagonistic manner, a double mutant NGR $\Omega r h c N \Delta r m l B-w b g A$ was constructed, and its symbiotic phenotype was assessed (Fig. 5). On P. tuberosus roots, the wild-type strain induces the formation of very few nodules. A similar result was observed when plants were inoculated with NGR $\Delta r m l B-w b g A$. Interestingly, whereas the $r h c N$ mu-

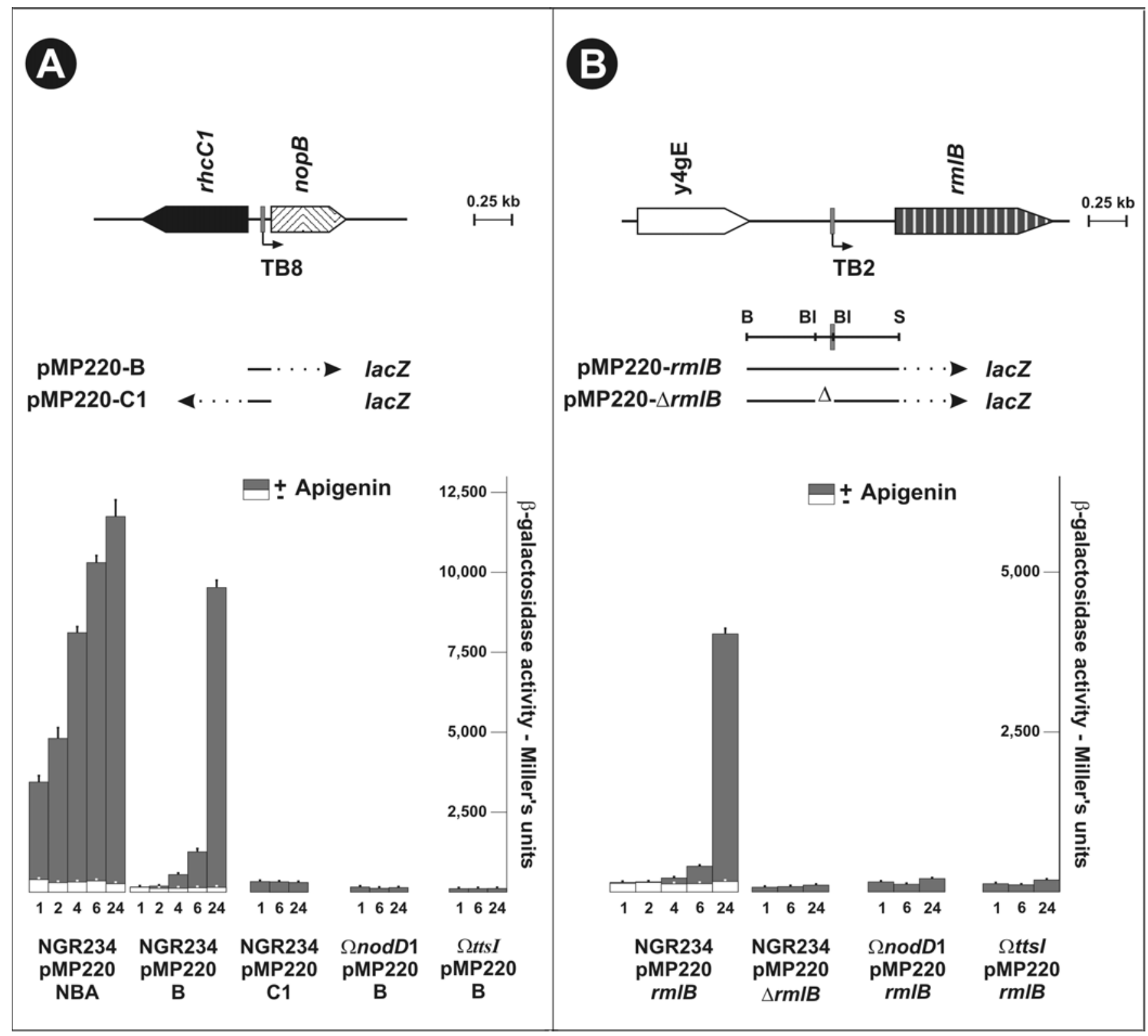

Fig. 4. Transcriptional activation of both nopB and $r m l B$ occurs between 2 and $4 \mathrm{~h}$ after induction and is flavonoid-, NodD1-, and TtsI-dependent. The promoter regions of $n o p B$ (pMP220-B), $r h c C 1$ (pMP220-C1), and $r m l B$ (pMP220-rmlB) were cloned upstream of a promoterless lac $Z$ gene. $\beta$-Galactosidase activities were measured at different times after induction and in various genetic backgrounds: NGR234, NGR $\Omega$ nodD1 ( $\Omega$ nodD1), and NGR $\Omega t t s I(\Omega t t s I)$. As a comparison, enzymatic activities driven by the promoter of nodABC (pMP220-NBA) are also shown. Transcriptional activation of A, nopB and $\mathbf{B}$, $r m l B$ occurred between 2 and $4 \mathrm{~h}$ after induction and required NodD1 as well as TtsI. Deletion of a DNA sequence containing the tts box located upstream of $r m l B$ (pMP220 $\Delta r m l B$ ) reduced $\beta$-galactosidase activities to basal levels. $r h c C 1$, which does not contain a tts box in its promoter region, is constitutively expressed, further showing the requirement of this cis-acting element for transcriptional activation by TtsI. Standard errors of the means are indicated above the bars. Each measurement was repeated at least three times. Restriction sites: $\mathrm{B}=B a m \mathrm{HI}, \mathrm{Bl}=B l p \mathrm{I}, \mathrm{S}=S f o \mathrm{I}$. 
tant nodulates this plant species with a high efficiency (Fig. 5), nodule formation was considerably reduced when both the $r h c N$ and $r m l B D A-w b g A$ genes were mutated. This indicates that, on $P$. tuberosus, rhamnan synthesis is indeed necessary for nodule formation but its requirement can only be observed when the symbiotic interaction is not compromised by Nop secretion. Since the phenotypes of NGR $\Omega r h c N \Delta r m l B$-wbgA and NGR $\Omega$ ttsI differ (Fig. 5), other factors under the control of TtsI probably contribute to the interaction between NGR234 and P. tuberosus. On plants of $T$. vogelii that require Nops for optimal nodulation, the loss of rhamnan synthesis leads to a greater decrease in nodule number than that caused by the abolition of Nop secretion. The symbiotic phenotypes of NGR $\Omega r h c N \Delta r m l B-w b g A$ and NGR $\Omega t t s I$ are similar, which suggests that one or more additional TtsI-controlled factors that are symbiotically relevant during the nodulation of $P$. tuberosus are not important during the interaction with $T$. vogelii. On both legumes, introduction of pttsI into NGR $\Omega$ ttsI leads to a number of nodules that is similar to that seen with NGR $\Omega r h c N$, further implying that one or both of the genes downstream of $t t s I: r h c C 2, \mathrm{y} 4 \mathrm{xK}$ are required for Nop secretion.

\section{DISCUSSION}

Formation of nitrogen-fixing nodules requires different types of bacterial signals that play important roles at various stages of the symbiosis. NGR234 is peculiar in that it is able to synthesize a variety of Nod factors (with at least 80 different structures), secrete proteins via a type III secretion system, and produce rhamnose-rich LPS (Broughton et al. 2000; Fraysse et al. 2002; Marie et al. 2003; Perret et al. 2000; Viprey et al. 1998). Although the synthesis of the last two symbiotic factors occurs via distinct metabolic pathways, they share the same regulatory network involving flavonoids, NodD1, and TtsI. We have shown that TtsI is a transcriptional activator of the nopB operon, which contains many genes involved in Nop secretion, as well as the $r m l B$ operon required for rhamnose synthesis, both of which contain a tts box in their promoter regions. TtsI belongs to the family of two-component regulatory systems that consist of a sensor histidine protein kinase and a response regulator protein. Histidine kinases monitor external stimuli and can auto-phosphorylate at a histidine residue. The phosphoryl group is subsequently transferred to an aspartate residue in the response regulator protein, so inducing a conformational change that eventually leads to its activation (Stock et al. 2000). Although TtsI proteins of NGR234 and other TTSS-containing rhizobia are homologous to response regulator proteins, they all contain a glutamate residue instead of the conserved aspartate residue shown to be the primary phosphate acceptor site in OmpR from E. coli and NtrC of Salmonella typhimurium (Delgado et al. 1993; Klose et al. 1993; Lan and Igo 1998). An amino acid exchange from aspartate to glutamate in OmpR or NtrC leads to the constitutive activation of these proteins and thus bypasses the requirement for the sensor kinase partner (Klose et al. 1993; Lan and Igo 1998). This suggests that TtsI may not need to be phosphorylated to be functional. Instead, a response to the external environment (i.e., the presence of the plant) would be mediated by transcriptional activation of $t t s I$ by flavonoids and NodD1. Once expressed, TtsI would then trigger the expression of i) the nop and $r h c$ genes, ii) several genes involved in rhamnan synthesis, iii) genes that encode proteins homologous to virulence factors, and iv) an operon involved in plasmid partitioning.

Identification of $t t s$ boxes in the promoter regions of $\mathrm{y} 4 \mathrm{fR}$, $\mathrm{y} 410$, and $\mathrm{y} 4 \mathrm{zC}$ suggests that the putative proteins might be secreted via the TTSS, as their Yersinia homologs are known to be. YopJ (homologous to y410) and YopT (homologous to $\mathrm{y} 4 \mathrm{zC}$ ) are proteins that define two families of cysteine proteases that can alter eukaryotic cell signaling events (Innes 2003). y4fR is homologous to the Yersinia YopM protein that is targeted into cell nuclei, in which it seems to play a role in the regulation of a number of mammalian genes involved in the cell cycle, cell growth, and reorganization of the cytoskeleton (Sauvonnet et al. 2002). Once injected into plant cells, the rhizobial proteins probably interfere with the eukaryotic cellular metabolism, altering either plant defense reactions or the signaling networks involved in nodule formation.

One $t t s$ box is located upstream of $\mathrm{y} 4 \mathrm{mFE}$ that encode proteins homologous to the NGR234 y4dLM and E. coli HipAB proteins (Freiberg et al. 1997). Both y4mFE and y4dLM are involved in plasmid stabilization in $R$. etli (Dombrecht et al. 2001), suggesting a similar function in NGR234. Nevertheless, a $t t s$ box was only identified upstream of y4mFE. The significance of this observation is unknown. One can speculate that expression of genes encoding virulence-like factors secreted via the TTSS can be deleterious during the interaction of NGR234 with some plant species, such as $P$. tuberosus. To guarantee the stability of pNGR234a, the bacteria might have developed a mechanism that assures coregulation of $\mathrm{y} 4 \mathrm{mFE}$ and TTSS-related genes.

\section{Role of rhamnose-rich LPS in symbiosis.}

Two $t$ ts boxes were identified in the region that contains several genes involved in the synthesis of rhamnan. TtsI as well as the region containing the $t$ ts box located upstream of $r m l B$ are required for transcriptional activation of the down-
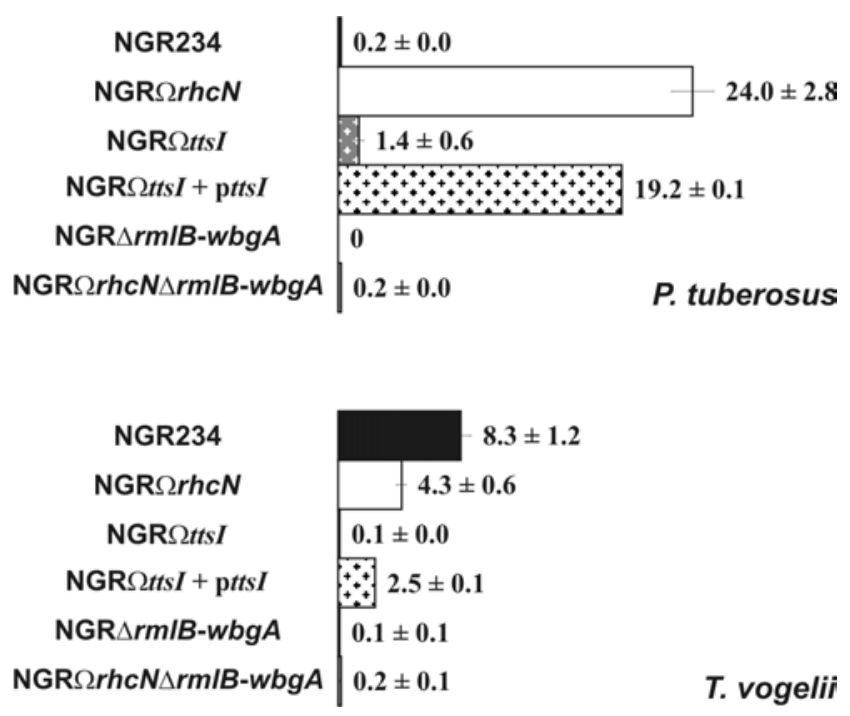

Fig. 5. The effect of abolition of nodulation outer protein (Nop) secretion, rhamnan synthesis, or both on nodule formation. The symbiotic phenotypes of NGR234 and various mutants (NGR $\Omega r h c N$, NGR $\Omega$ ttsI, NGR $\Omega$ ttsI (pttsI), NGR $\Delta r m l B-w b g A$, and NGR $\Omega r h c N \Delta r m l B-$ $\omega \operatorname{bg} A$ ) were tested on the two plant models shown to respond to nodulation outer proteins (Nops) (Viprey et al. 1998). On both plants, the symbiotic phenotypes of the rhcN and ttsI mutants differ. On $T e$ phrosia vogelii, which responds positively to Nops, rhamnan synthesis seems to play a major role during the nodulation process. On Pachyrhizus tuberosus, the phenotype of the double mutant shows that rhamnose-rich lipopolysaccharide synthesis is indeed required when normal nodule development is not impaired by Nop secretion. The nodule number obtained with NGR $\Omega$ ttsI and NGR $\Omega r h c N \Delta r m l B$-wbgA differs, suggesting that other factors regulated by TtsI are involved in the interaction between NGR234 and this plant species. The average number of nodules and standard errors of the means are indicated adjacent to the bars. Independent experiments were performed at least three times, using 10 to 15 plants in each case. 
stream genes. Although a TtsI homolog and tts boxes were identified in all rhizobial strains containing components of the TTSS (Krause et al. 2002; Marie et al. 2001), the coordinated regulation of Nop secretion and rhamnan synthesis does not seem to be ubiquitous. Genes involved in rhamnose synthesis were not identified in the fully sequenced genome of Bradyrhizobium japonicum USDA110 (Kaneko et al. 2002). Furthermore, rhamnose-rich LPS similar to those produced by NGR234 were not detected when polysaccharides from $R$. fredii USDA257 were extracted with hot phenol (data not shown). Of those rhizobia that possess a TTSS, only Mesorhizobium loti MAFF303099 also contains rmlABCD homologs (designated mlr7550 to mlr7553) (Kaneko et al. 2000). Analysis of their promoter regions led to the identification (39 bp upstream of mlr7550) of a nucleotide stretch (cgGTCAGggccggGgggct) that shares similarities with the $t t s$ box consensus. It is of interest to determine whether $M$. loti MAFF303099 also produces rhamnose-rich LPS in a flavonoid and TtsI-dependent manner.

Genes homologous to $r m l A B C D$ are also found in rhizobia that do not appear to contain a TTSS, $R$. meliloti 1021 (Galibert et al. 2001) and Azorhizobium caulinodans (Gao et al. 2001). Although the function of the $r m l$ homologs in $R$. meliloti is unknown, a mutation in oac2 (homologous to $r m l D$ of NGR234) of $A$. caulinodans leads to the formation of a truncated LPS and the formation of nonfixing nodulelike structures on Sesbania rostrata (Gao et al. 2001). Rhamnose-rich LPS are thought to be required for the release of bacteria from infection threads and for protection of the bacteria against plant defense reactions (Gao et al. 2001). In NGR234, abolition of rhamnan synthesis has a strong impact on nodule formation as well as nitrogen fixation on many hosts, suggesting that rhamnose-rich LPS may have similar functions.

Thus, TtsI is a key component of a regulatory network involved in the synthesis of multiple symbiotic factors. Transcriptional analyses showed that the $t t s$ boxes are (most probably) required for activation of those genes regulated by TtsI. Further studies will determine whether TtsI binds to the cisacting elements or if another intermediary regulator is involved. Completion of the sequence of the NGR234 genome will probably lead to the detection of additional $t t s$ boxes and allow for the identification of other genes under TtsI control. Dissection of the regulatory network of genes that play roles in the synthesis of symbiotic factors will undoubtedly help explain the broad host range of NGR234.

\section{MATERIALS AND METHODS}

\section{Microbial and molecular techniques.}

Bacterial strains and plasmids used in this study are listed in Table 1. E. coli strains were grown in Luria-Bertani media at $37^{\circ} \mathrm{C}$ (Sambrook et al. 1989). Rhizobium strains were grown at $27^{\circ} \mathrm{C}$ in either complete (TY) (Beringer 1974) or minimal media (RMS, using succinate as a carbon source at a final concentration of $12 \mathrm{mM}$ ) (Broughton et al. 1986). Antibiotics were added to the media at the following final concen-

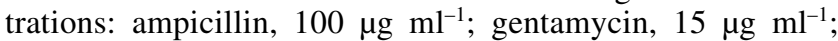

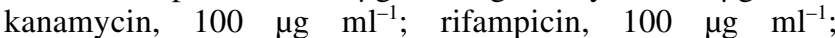

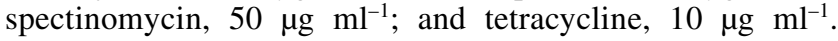
Where indicated, cultures were induced with apigenin at a final concentration of $10^{-6} \mathrm{M}$.

Table 1. Bacterial strains and plasmids used in this study

\begin{tabular}{|c|c|c|}
\hline Strain or plasmid & Relevant characteristics $^{\mathbf{a}}$ & Reference or source \\
\hline \multicolumn{3}{|l|}{ Escherichia coli strain } \\
\hline DH5 $\alpha$ & supE44 $\Delta l a c \mathrm{U} 169$ ( $\$ 80$ lacZAM15) hsdR17 recA1 endA1 gyrA96 thi-1 relA1 & BRL, Bethesda, MD, U.S.A. \\
\hline \multicolumn{3}{|c|}{ 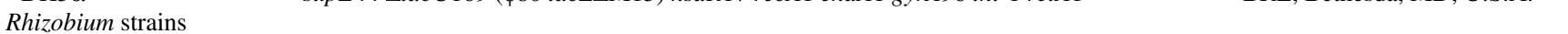 } \\
\hline NGR234 & $\begin{array}{l}\text { Rif }^{\mathrm{r}} \text { derivative of the broad-host-range bacterium isolated from nodules of Lablab } \\
\text { purpureus }\end{array}$ & Stanley et al. 1988 \\
\hline NGR $\Omega$ nodD1 & $\begin{array}{l}\text { NGR234 derivative containing an } \Omega \text { cassette inserted into the BamHI site of nodD1, } \\
\text { Rif }^{r}, S^{r}\end{array}$ & Relić et al. 1993 \\
\hline NGR $\Delta r m l B-w b g A$ & $\begin{array}{l}\text { NGR234 derivative in which the } 3.7-\mathrm{kb} \text { EcoRV fragment containing } r m l B \text {-wbgA was } \\
\text { replaced by an } \Omega \text { cassette, } \mathrm{Rif}^{\mathrm{r}}, \mathrm{Km}^{\mathrm{r}}\end{array}$ & Broughton et al. 2004 \\
\hline $\mathrm{NGR} \Omega r h c N$ & NGR234 derivative containing an $\Omega$ cassette inserted into the $E c o R I$ site of $r h c N, \mathrm{Rif}^{\mathrm{r}}, \mathrm{Sp}^{\mathrm{r}}$ & Viprey et al. 1998 \\
\hline NGR $\Omega r h c N \Delta r m l B-w b g A$ & $\begin{array}{l}\mathrm{NGR} \Omega r h c N \text { derivative containing a deletion encompassing the } r m l B, r m l D, r m l A \text {, and } \\
w b g A \text { genes, } \operatorname{Rif}^{\mathrm{r}}, \mathrm{Sp}^{\mathrm{r}}, \mathrm{Km}^{\mathrm{r}}\end{array}$ & This work \\
\hline NGR $\Omega$ ttsI & NGR234 derivative containing an $\Omega$ cassette inserted into the $A p a I$ site of $t t s I, \operatorname{Rif}^{\mathrm{r}}, \mathrm{Sp}^{\mathrm{r}}$ & Viprey et al. 1998 \\
\hline \multicolumn{3}{|c|}{${ }^{2}$} \\
\hline pBluescript II KS+ & High copy number ColE1-based phagemid, $\mathrm{Ap}^{\mathrm{r}}$ & Stratagene, La Jolla, CA, U.S.A. \\
\hline pJQ200SK & Suicide vector used to generate directed mutagenesis, $\mathrm{Ge}^{\mathrm{r}}$ & Quandt and Hynes 1993 \\
\hline $\mathrm{pJQ} \Omega \mathrm{gFGHI}$ & $\begin{array}{l}\text { pJQ200SK derivative carrying part of } r m l B \text {, an } \Omega-\mathrm{Km}^{\mathrm{r}} \text { interposon and part of } w b g A \text {, } \\
\mathrm{Ge}^{\mathrm{r}}, \mathrm{Km}^{\mathrm{r}}\end{array}$ & $\begin{array}{l}\text { X. Perret and B. Bordogna } \\
\text { unpublished data }\end{array}$ \\
\hline $\mathrm{pKS}-r m l B$ & $\mathrm{pKS}+$ derivative containing the $\mathrm{y} 4 \mathrm{gE}-\mathrm{rm} l B$ intergenic region & This work \\
\hline pKS- $\Delta r m l B$ & $\begin{array}{l}\text { pKS-rmlB derivative in which the approximately } 0.1-\mathrm{kb} B l p \mathrm{I} \text { fragment containing the } \\
t t s \text {-box was deleted }\end{array}$ & This work \\
\hline pLAFR-6 & $\begin{array}{l}\text { Broad-host-range vector containing transcriptional terminators flanking cloning sites, } \\
\mathrm{Tc}^{\mathrm{r}}\end{array}$ & $\begin{array}{l}\text { Dahlbeck and Staskawicz } \\
\text { unpublished data }\end{array}$ \\
\hline pMP220 & Expression vector containing a promoterless lac $Z$ gene, $\mathrm{Tc}^{\mathrm{r}}$ & Spaink et al. 1987 \\
\hline pMP220-B & $\begin{array}{l}\text { pMP220 derivative containing the nopB (previously called nolB) promoter region } \\
\text { upstream of lac } Z\end{array}$ & This work \\
\hline pMP220-C1 & $\begin{array}{l}\text { pMP220 derivative containing the } r h c C 1 \text { (previously called nolW) promoter region } \\
\text { upstream of } l a c Z\end{array}$ & This work \\
\hline pMP220-NBA & pMP220 derivative containing the nodABC nod-box upstream of lacZ & Fellay et al. 1998 \\
\hline pMP220-rmlB & pMP220 derivative containing the $r m l B$ promoter region upstream of $l a c Z$ & This work \\
\hline pMP220- $\Delta r m l B$ & pMP220-rmlB derivative with a deletion encompassing the $t t s$-box & This work \\
\hline pttsI & $\begin{array}{l}\text { pLAFR- } 6 \text { derivative containing a } 1.5-\mathrm{kb} \text { fragment with the } t \text { tsI gene under the control of } \\
\text { nod-box } 18\end{array}$ & This work \\
\hline pXB110 & Lorist 2 derivative containing the $\mathrm{y} 4 \mathrm{xA}$ to $\mathrm{y} 4 \mathrm{yP}$ region of $\mathrm{pNGR} 234 \mathrm{a}, \mathrm{Km}^{\mathrm{r}}$ & Perret et al. 1991 \\
\hline pXB285 & Lorist 2 derivative containing the $\mathrm{y} 4 \mathrm{gC}$ to $44 \mathrm{hM}$ region of pNGR $234 a, \mathrm{Km}^{\mathrm{r}}$ & Perret et al. 1991 \\
\hline
\end{tabular}

${ }^{\mathrm{a}} \mathrm{Ap}=$ ampicillin; $\mathrm{Ge}=$ gentamycin $\mathrm{Km}=$ kanamycin; Rif = rifampicin; $\mathrm{Sp}=$ spectinomycin; $\mathrm{Tc}=$ tetracycline; and the superscript $\mathrm{r}=$ resistant. 
Standard molecular cloning techniques were carried out as described in Sambrook and associates (1989). To obtain pttsI, a 2.4-kb PstI fragment containing the promoter and coding regions of ttsI was isolated from pXB110 (Perret et al. 1991) and was subcloned into the PstI site of pUC18 (A. Del Greco and $\mathrm{X}$. Perret, unpublished data). The resulting plasmid, called pUC::ttsI, was then digested with PstI and NheI to release a $1.5-\mathrm{kb}$ fragment that was introduced into the broad-host-range vector pLAFR-6 (previously digested with PstI and XbaI), yielding pttsI. To clone the intergenic region located between $\mathrm{y} 4 \mathrm{gE}$ and $\mathrm{rmlB}$, a 5.6-kb BamHI-ApaI fragment covering the DNA sequence from the $3^{\prime}$ end of $\mathrm{y} 4 \mathrm{gE}$ to the $3^{\prime}$ end of $w b g A$ was first isolated from pXB285 (Perret et al. 1991) and was cloned into pBluescript II KS+. An approximately $1.0-\mathrm{kb}$ NotI-SfoI (from the multiple cloning site of the vector and beginning of $r m l B$, respectively) fragment was then subcloned into pBluescript II KS+ digested with SmaI. The resulting plasmid, pKS-rmlB, was then digested with $B a m \mathrm{HI}$, and the $1.0-\mathrm{kb}$ fragment was inserted into pMP220 digested with $B g l I I$, to give pMP220-rmlB. To construct pMP220- $\Delta r m l B$, pKS-rmlB was first digested with $B l p I$ to delete the 119-bp internal fragment containing the $t t s$ box. The approximately 0.9-kb BamHI fragment was then ligated into pMP220 digested with $B g l I I$, to give pMP220- $\Delta r m l B$. Plasmids were mobilized from E. coli DH5 $\alpha$ to Rhizobium strains by triparental matings, using the helper plasmid pRK2013 (Figurski and Helinski 1979).

An NGR234 derivative containing both a mutation in $r h c N$ and a deletion encompassing the $r m l B$-wbgA genes was obtained by introducing the suicide plasmid pJQ $\Omega$ gFGHI into the $r h c N$ mutant by triparental matings. Double recombination was selected by plating bacteria onto RMS plates containing $5 \%(\mathrm{wt} / \mathrm{vol})$ sucrose and the appropriate antibiotics. Putative mutants were confirmed by probing Southern blots of restricted genomic DNA, using standard procedures (Chen and Kuo 1993; Sambrook et al. 1989).

\section{Measurements of $\beta$-galactosidase activity.}

$\beta$-Galactosidase activities were measured according to the method described by Miller (1972). The cells were grown in RMS to a saturated culture and were diluted to obtain an optical density at $600 \mathrm{~nm}\left(\mathrm{OD}_{600}\right)$ of approximately 0.1 . Aliquots were then taken at different times, and the cells were lysed using sodium dodecyl sulfate (SDS) and chloroform. $\beta$-Galactosidase activities were determined by measuring the production of $o$-nitrophenol from $o$-nitrophenyl- $\beta$-D-galactoside.

\section{Analysis of polysaccharides and secreted proteins.}

Polysaccharides were extracted using a hot-phenol purification procedure. Rhizobium strains were grown in RMS for 72 $\mathrm{h}$ to an $\mathrm{OD}_{600}$ of approximately 0.8. Cell pellets were resuspended in water and were mixed with an equal volume of hot $\left(65^{\circ} \mathrm{C}\right)$ phenol $(90 \%, \mathrm{vol} / \mathrm{vol})$. Following centrifugation, the aqueous phases were removed and dialyzed against water. Polysaccharides were then separated on $16 \%$ polyacrylamide gels, using deoxycholic acid as a detergent, and were eventually stained with silver nitrate.

Secreted proteins were purified and analyzed as described in Marie and associates (2003). Rhizobium strains were grown for $40 \mathrm{~h}$ in RMS supplemented with apigenin. Secreted proteins present in the supernatants of cultures were precipitated using ammonium sulphate $(60 \%$, wt/vol) and subsequently desalted using Sephadex G25-containing columns (Amersham Biosciences, Uppsala, Sweden). Proteins were then separated by SDS-polyacrylamide gel electrophoresis (16\% acrylamide), prior to staining with silver nitrate. Molecular weight markers for proteins were purchased from Amersham Biosciences.
Identification of $\boldsymbol{t t s}$ boxes located on pNGR234a.

Initially the $t$ ts box consensus sequence proposed by Krause and associates (2002) was used to search pNGR234 $\alpha$, using a variety of programs, but the consensus sequence was too degenerate at the $3^{\prime}$ end to give clear predictions. The consensus sequence was thus shortened to a more conserved 20-bp sequence, "tcGTCAGcTT-tcGaaAGct," in which capital letters represent invariant residues and the dash any residue. This sequence was used with the DNA Strider software package to search the TTSS locus of pNGR234a. The most stringent parameters (five mismatches and one gap) were applied, which allowed detection of the four NGR234 tts boxes previously described (Krause et al. 2002). Furthermore these parameters detected $t t s$ boxes in the promoter regions of all the NGR234 TTSS regulons, with the exception of $r h c C 1$. The search was then expanded to each section of pNGR234a (Freiberg et al. 1997), to give the results shown in Figure 1. The alignment in Figure 1A was created using the ClustalW and Boxshade programs hosted at the Swiss EMBnet, website. A graphical representation of the consensus was then generated using the European Bioinformatics Institute SEQLOGO program to show the relative proportion of each residue in the pNGR234a tts-box consensus, as shown in Figure 1B.

\section{Plant tests.}

Suppliers from which seeds were purchased are listed in Pueppke and Broughton (1999). Nodulation tests were performed in Magenta jars as described in Viprey and associates (1998).

\section{ACKNOWLEDGMENTS}

We wish to thank Y.-Y. Aung and D. Gerber for their unstinting help. This work was supported by the Fonds National de la Recherche Scientifique (Project 31-63893.00) and the Université de Genève.

\section{LITERATURE CITED}

Ausmees, N., Kobayashi, H., Deakin, W. J., Marie, C., Krishnan, H. B., Broughton, W. J., and Perret, X. 2004. Characterization of NopP, a type III secreted effector of Rhizobium sp. strain NGR234. J. Bacteriol. July 001. Published online.

Becker, A., and Pühler, A. 1998. Production of exopolysaccharides. Pages 97-118 in: The Rhizobiaceae. H. P. Spaink, A. Kondorosi, and P. J. J. Hooykaas, eds. Kluwer Academic Publishers, Dordrecht, The Netherlands.

Beringer, J. E. 1974. R-factor transfer in Rhizobium leguminosarum. J. Gen. Microbiol. 84:188-198.

Broughton, W. J., Wong, C.-H., Lewin, A., Samrey, U., Myint, H., Meyer z. A., H., Dowling, D. N., and Simon, R. 1986. Identification of Rhizobium plasmid sequences involved in recognition of Psophocarpus, Vigna, and other legumes. J. Cell Biol. 102:1173-1182.

Broughton, W. J., Jabbouri, S., and Perret, X. 2000. Keys to symbiotic harmony. J. Bacteriol. 182:5641-5652.

Chen, W.-P., and Kuo, T.-t. 1993. A simple and rapid method for the preparation of gram-negative bacterial genomic DNA. Nucleic Acids Res. 21:2260.

Delgado, J., Forst, S., Harlocker, S., and Inouye, M. 1993. Identification of a phosphorylation site and functional analysis of conserved aspartic acid residues of OmpR, a transcriptional activator for $o m p F$ and $o m p C$ in Escherichia coli. Mol. Microbiol. 10:1037-1047.

Dombrecht, B., Vanderleyden, J., and Michiels, J. 2001. Stable RK2derived cloning vectors for the analysis of gene expression and gene function in gram-negative bacteria. Mol. Plant-Microbe Interact. 14:426-430.

Falla, T. J., and Chopra, I. 1999. Stabilization of Rhizobium symbiosis plasmids. Microbiology 145:515-516.

Fellay, R., Hanin, M., Montorzi, G., Frey, J., Freiberg, C., Golinowski, W., Staehelin, C., Broughton, W. J., and Jabbouri, S. 1998. nodD2 of Rhizobium sp. NGR234 is involved in the repression of the nodABC operon. Mol. Microbiol. 27:1039-1050. 
Figurski, D. H., and Helinski, D. R. 1979. Replication of an origin-containing derivative of plasmid RK2 dependent on a plasmid function provided in trans. Proc. Natl. Acad. Sci. U.S.A. 76:1648-1652.

Fraysse, N., Jabbouri, S., Treilhou, M., Couderc, F., and Poinsot, V. 2002. Symbiotic conditions induce structural modifications of Sinorhizobium sp. NGR234 surface polysaccharides. Glycobiology 12:741-748.

Freiberg, C., Fellay, R., Bairoch, A., Broughton, W. J., Rosenthal, A., and Perret, X. 1997. Molecular basis of symbiosis between Rhizobium and legumes. Nature 387:394-401.

Galibert, F., Finan, T. M., Long, S. R., Pühler, A., Abola, P., Ampe, F., Barloy-Hubler, F., Barnett, M. J., Becker, A., Boistard, P., Bothe, G., Boutry, M., Bowser, L., Buhrmester, J., Cadieu, E., Capela, D., Chain, P., Cowie, A., Davis, R. W., Dréano, S., Federspiel, N. A., Fischer, R. F. Gloux, S., Godrie, T., Goffeau, A., Golding, B., Gouzy, J., Gurjal, M., Hernandez-Lucas, I., Hong, A., Huizar, L., Hyman, R. W., Jones, T., Kahn, D., Kahn, M. L., Kalman, S., Keating, D. H., Kiss, E., Komp, C., Lelaure, V., Masuy, D., Palm, C., Peck, M. C., Pohl, T. M., Portetelle, D., Purnelle, B., Ramsperger, U., Surzycki, R., Thébault, P., Vandenbol, M., Vorhölter, F.-J., Weidner, S., Wells, D. H., Wong, K., Yeh, K.-C., and Batut, J. 2001. The composite genome of the legume symbiont Sinorhizobium meliloti. Science 293:668-672.

Gao, M., D’Haeze, W., De Rycke, R., Wolucka, B., and Holsters, M. 2001 Knockout of an Azorhizobial dTDP-L-rhamnose synthase affects lipopolysaccharide and extracellular polysaccharide production and disables symbiosis with Sesbania rostrata. Mol. Plant-Microbe Interact. 14:857-866

Hanin, M., Jabbouri, S., Broughton, W. J., and Fellay, R. 1998. SyrM1 of Rhizobium sp. NGR234 activates transcription of symbiotic loci and controls the level of sulfated Nod factors. Mol. Plant-Microbe Interact. 11:343-350.

Innes, R. 2003. New effects of type III effectors. Mol. Microbiol. 50:363365

Jabbouri, S., Hanin, M., Fellay, R., Quesada-Vincens, D., Reuhs, B. L., Carlson, R. W., Perret, X., Freiberg, C., Rosenthal, A., Leclerc, D., Broughton, W. J., and Relić, B. 1996. Rhizobium species NGR234 hostspecificity of nodulation locus III contains nod and fix genes. Pages 319-324 in: Biology of Plant-Microbe Interactions. G. Stacey, B. Mullin, and P. M. Gresshoff, eds. International Society for Molecular Plant-Microbe Interactions, St. Paul, MN, U.S.A

Kaneko, T., Nakamura, Y., Sato, S., Asamizu, E., Kato, T., Sasamato, S., Watanabe, A., Idesawa, K., Ishikawa, A., Kawashima, K., Kimura, T., Kishida, Y., Kiyokawa, C., Kohara, M., Matsumoto, M., Matsuno, A., Mochizuki, Y., Nakayama, S., Nakazaki, N., Shimpo, S., Sugimoto, M., Takeuchi, C., Yamada, M., and Tabata, S. 2000. Complete genome structure of the nitrogen-fixing symbiotic bacterium Mesorhizobium loti. DNA Res. 7:331-338.

Kaneko, T., Nakamura, Y., Sato, S., Minamisawa, K., Uchiumi, T., Sasamoto, S., Watanal, A., Idesawa, K., Iriguchi, M., Kawashima, K., Kohara, M., Matsumoto, M., Shimpo, S., Tsuruoka, H., Wada, T., Yamada, M., and Tabata, S. 2002. Complete genomic sequence of nitrogen-fixing symbiotic bacterium Bradyrhizobium japonicum USDA110. DNA Res. 9:189-197.

Kannenberg, E. L., Reuhs, B. L., Forsberg, L. S., and Carlson, R. W. 1998. Lipopolysaccharides and K-antigens: Their structures, biosynthesis and functions. Pages 119-154 in: The Rhizobiaceae. H. P. Spaink, A. Kondorosi, and P. J. J. Hooykaas, eds. Kluwer Academic Publishers, Dordrecht, The Netherlands.

Klose, K. E., Weiss, D. S., and Kustu, S. 1993. Glutamate at the site of phosphorylation of nitrogen-regulatory protein NTRC mimics aspartylphosphate and activates the protein. J. Mol. Biol. 232:67-78.

Kobayashi, H., Naciri-Graven, Y., Broughton, W. J., and Perret, X. 2004. Flavonoids induce temporal shifts in gene-expression of nod-box controlled loci in Rhizobium sp. NGR234. Mol. Microbiol. 51:335-347.
Krause, A., Doerfel, A., and Göttfert, M. 2002. Mutational and transcriptional analysis of the type III secretion system of Bradyrhizobium japonicum. Mol. Plant-Microbe Interact. 15:1228-1235.

Lan, C.-Y., and Igo, M. M. 1998. Differential expression of the OmpF and OmpC porin proteins in Escherichia coli $\mathrm{K}-12$ depends upon the level of active OmpR. J. Bacteriol. 180:171-174.

Marie, C., Broughton, W. J., and Deakin, W. J. 2001. Rhizobium type III secretion systems: Legume charmers or alarmers? Curr. Opin. Plant Biol. 4:336-342.

Marie, C., Deakin, W. J., Viprey, V., Kopciñska, J., Golinowski, W., Krishnan, H. B., Perret, X., and Broughton, W. J. 2003. Characterization of Nops, nodulation outer proteins, secreted via the type III secretion system of NGR234. Mol. Plant-Microbe Interact. 16:743-751.

Miller, J. H. 1972. Assay of $\beta$-galactosidase. Pages 352-355 in: Experiments in Molecular Genetics. J. H. Miller, ed. Cold Spring Harbor Laboratory Press, Cold Spring Harbor, NY, U.S.A

Perret, X., Broughton, W. J., and Brenner, S. 1991. Canonical ordered cosmid library of the symbiotic plasmid of Rhizobium species NGR234. Proc. Natl. Acad. Sci. U.S.A. 88:1923-1927.

Perret, X., Freiberg, C., Rosenthal, A., Broughton, W. J., and Fellay, R. 1999. High-resolution transcriptional analysis of the symbiotic plasmid of Rhizobium sp. NGR234. Mol. Microbiol. 32:415-425.

Perret, X., Staehelin, C., and Broughton, W. J. 2000. Molecular basis of symbiotic promiscuity. Microbiol. Mol. Biol. Rev. 64:180-201.

Perret, X., Kobayashi, H., and Collado-Vides, J. 2003. Regulation of expression of symbiotic genes in Rhizobium species NGR234. Indian J. Exp. Biol. 41:1101-1113.

Pueppke, S. G., and Broughton, W. J. 1999. Rhizobium sp. strain NGR234 and $R$. fredii USDA257 share exceptionally broad, nested host range. Mol. Plant-Microbe Interact. 12:293-318.

Quandt, J., and Hynes, M. F. 1993. Versatile suicide vectors which allow direct selection for gene replacement in gram-negative bacteria. Gene 127:15-21.

Relić, B., Fellay, R., Lewin, A., Perret, X., Price, N. P. J., Rochepeau, P., and Broughton, W. J. 1993. nod genes and Nod factors of Rhizobium species NGR234. Pages 183-189 in: New Horizons in Nitrogen Fixation. R. Palacios, J. Mora, and W. E. Newton, eds. Kluwer Academic Publishers, Dordrecht, The Netherlands.

Sambrook, J., Fritsch, E. F., and Maniatis, T. 1989. Molecular Cloning: A Laboratory Manual, 2nd ed. Cold Spring Harbor Laboratory Press, Cold Spring Harbor, NY, U.S.A.

Sauvonnet, N., Pradet-Balade, B., Garcia-Sanz, J. A., and Cornelis, G. R. 2002. Regulation of mRNA expression in macrophages after Yersinia enterocolitica infection. Role of different Yop effectors. J. Biol. Chem. 277:25133-25142.

Spaink, H. P., Okker, R. J. H., Wijffelman, C. A., Pees, E., and Lugtenberg, B. J. J. 1987. Promoters in the nodulation region of the Rhizobium leguminosarum Sym plasmid pRL1JI. Plant Mol. Biol. 9:27-39.

Stanley, J., Dowling, D. N., and Broughton, W. J. 1988. Cloning of hemA from Rhizobium sp. NGR234 and symbiotic phenotype of a genedirected mutant in diverse legume genera. Mol. Gen. Genet. 215:32-37.

Stock, A. M., Robinson, V. L., and Goudreau, P. N. 2000. Two-component signal transduction. Annu. Rev. Biochem. 69:183-215.

Viprey, V., Del Greco, A., Golinowski, W., Broughton, W. J., and Perret, X. 1998. Symbiotic implications of type III protein secretion machinery in Rhizobium. Mol. Microbiol. 28:1381-1389.

\section{AUTHOR-RECOMMENDED INTERNET RESOURCES}

The Swiss node of EMBnet: www.ch.embnet.org

European Bioinformatic Institute SEQLOGO expression profiler: ep.ebi.ac.uk/EP/SEQLOGO 